\title{
Statutory Holiday
}

National Cancer Institute

\section{Source}

National Cancer Institute. Statutory Holiday. NCI Thesaurus. Code C148292.

Cultural, nationalistic, and religious holidays that are legislated by the government. 